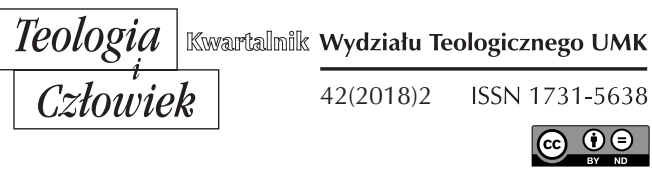

PIOTR POPIOŁEK*

KRAKÓW

ORCID: 0000-0002-7986-480X

\title{
MARIOFANIA. ROLA MARYI W DIALOGU MIĘDZYRELIGIJNYM
}

DOI: http://dx.doi.org/10.12775/TiCz.2018.021

\section{WSTĘP}

Guanyin (jap. Kannon) i Maryja są najprawdopodobniej dwiema najbardziej rozpowszechnionymi na świecie żeńskimi postaciami, będącymi manifestacjami pewnej świętej rzeczywistości. Jednakże sama popularność tych osób $\mathrm{w}$ tradycjach religijnych nie jest jedyną rzeczą, która je łączy. Oczywiste jest, że historyczna postać Maryi, Matki Bożej, Matki Jezusa, oraz niehistoryczna Guanshiyin, chińska odpowiedniczka bodhisattvy Avalokiteśvary, nie mają ze sobą niemalże nic wspólnego. Są to jednak figury i postaci, które poruszały umysły, wyobraźnie i serca milionów ludzi na całym świecie, które wyznaczały pewien wzór, dawały nadzieję i pocieszenie tym, którzy ich potrzebowali. Stanowiły one w ten

* Mgr lic. Teologii Uniwersytetu Papieskiego Jana Pawła II w Krakowie oraz lic. religioznawstwa Uniwersytetu Jagiellońskiego w Krakowie. W latach 2012-2013 stypendysta Hanbanu i BUWiWMu na Xi'an International Studies University w Chinach. Od 2014 r. doktoryzuje się na Katedrze Antropologii Teologicznej pod przewodnictwem ks. dra hab. Roberta Woźniaka na Wydziale Teologicznym UPJPII w Krakowie (piotr.s.popiolek@gmail.com). 
sposób ostoję, fundament dla pewnej tożsamości tak religijnej, jak i kulturowej. W języku teologii religii można by rzec, że owe gynomorficzne manifestacje sacrum, obiektywnej rzeczywistości, są sobie równoważne ontologicznie, różniąc się jedynie sposobem, w jaki owa rzeczywistość jest przedstawiana $\mathrm{w}$ języku i kulturze ${ }^{1}$. Jednak $\mathrm{z}$ racji tego, że taka interpretacja teologiczna jest w pewnym stopniu już na rubieżach teologii katolickiej o wątpliwie ortodoksyjnym charakterze (wpisująca się bardziej w teologię religii Johna Hicka), postanowiłem wykorzystać mniej kontrowersyjną metodologię: teologię dialogu Raimundo Panikkara.

Aby ukazać podstawy terminologiczne, którymi będę się posługiwać, pozwolę sobie sparafrazować słowa Panikkara:

Cokolwiek da się powiedzieć o prawdzie obiektywnej, wierzenie religijne jest rzeczą wysoce osobistą i subiektywną; wiara, która zbawia, jest zawsze osobista i subiektywna. Guanyin/Maryja z naszego dialogu nie jest postacią historyczną ani mitologiczną, ale Guanyin/Maryją wiary, osobistej wiary mego rozmówcy. Jego wierzenie jest wierzeniem, jakie muszę przyjąć, podzielając jego prawdę - prawdę, którą stanowi Guanyin/ Maryja wiary².

To, czego będziemy szukać, to z jednej strony Maryja i Guanyin doświadczenia wiary ${ }^{3}$. Pewne sposoby naszego postrzegania ich - wierzenia

1 Wtedy przedmiot poznania (w tym wypadku czci, kultu), noemat, jako obiektywna rzeczywistość byłby postrzegany przez podmiot poznający na podstawie posiadanych przez niego danych, treści symbolicznych uwarunkowanych kulturowo, społecznie itp., które stanowiłyby dane służące do werbalizacji i przedstawienia przez niego doświadczenia sacrum, hierofanii. Takie oddolne, subiektywizujące podejście nie jest jednak w pełni dopuszczalne w teologii katolickiej. Budzi ono również wiele zastrzeżeń u wielu badaczy, którzy wchodzili w dyskurs teologii i filozofii religii, jak np. u Levinasa czy Panikkara. Bóstwo nie może być tylko przedmiotem, który jest ciężko uchwycić ze względu na ograniczoną ludzką percepcję - jest przede wszystkim Bogiem, który się daje, działa i daje się poznać. Nie jest też całkowicie transcendentny ze względu na działające Objawienie, które również nie powinno być postrzegane w sposób statyczny w postaci określonych, danych raz i konkretnych treści.

2 R. Panikkar, Religie świata $w$ dialogu, tłum. J. Marzęcki, Warszawa 1986. Cytat zmieniono, zastępując słowo Kryszna słowami Guanyin/Maryja. Rozstrzelenie tekstu także nie znajduje się w oryginale.

${ }^{3}$ Nie należałoby jednak pojmować tego w sposób czysto psychologiczny re- 
(treści wiary) - są fundamentalne dla naszej wiary. Są one jej wyrazem, językiem który stara się ją ująć w słowa.

W niniejszym artykule postaram się wyjść poza rekonstrukcję historii samej Maryi - jej rzeczywistości historycznej i kontekstu, w którym żyła - skupiając się na dwóch „opowieściach maryjnych” będących zarówno (lub przede wszystkim) przejawem dialogu chrześcijaństwa z religiami ościennymi (w tym przypadku rodzimymi). Owe dwie sytuacje historyczne obejmują zdarzenie, kiedy to kult Guanyin (jap. Kannon) miał bezpośredni kontakt $\mathrm{z}$ kultem ${ }^{4}$ maryjnym. Poprzez rekonstrukcję wydarzeń historycznych oraz ich kontekstu dokonam charakteryzacji relacji pomiędzy wierzeniami, będącymi treścią wiary konkretnych wspólnot. Oba podane przeze mnie przykłady charakteryzuje to, że są wynikiem zetknięcia się na terenach Azji Wschodniej tradycji chrześcijańskiej $\mathrm{z}$ tradycją buddyjską, a więc tam, gdzie chrześcijaństwo pojawiło się jako pewne novum, a zarazem ingerencja $\mathrm{z}$ zewnątrz (dokładnie z kraju barbarzyńców - jak był postrzegany Zachód). Tradycja chrześcijańska jest tą, która stara się zaadaptować do istniejących realiów Wschodu. Rezultaty tej akulturacji ${ }^{5}$ są różne w przypadku kościoła jingjiao w Chinach, jak i kirishitan w Japonii. Postanowiłem pominąć całą historię misji jezuickich w Chinach z tego względu, że uważam iż przykład jingjiao, jako chronologicznie poprzedzający szesnastowieczne misje, jest bardziej istotny. Ponadto, poszukując materiałów, nie znalazłem interesujących

dukując do pewnych dyspozycji i psychiki ludzkiej, sprowadzając w gruncie rzeczy doświadczenie wiary do „uczucia” obecnego w immanentnej świadomości i jedynie uzewnętrznianej przez pewien (pozornie) transcendentny przedmiot poznania. Chodzi tu o doświadczenie wiary żywej, angażującej całą egzystencję osoby ludzkiej, nastawionej intencjonalnie na transcendentny przedmiot wiary, jak i otwartość do dialogu. Taki przedmiot wiary, z którym następuje dialog, nie jest tylko przedmiotem, ale i podmiotem wiary, partnerem $\mathrm{w}$ dialogu.

${ }^{4}$ Zdaję sobie sprawę, że kult (łac. cultus) nie jest zawsze akceptowalnym pojęciem określającym stosunek wiernych do Maryi i częściej za prawidłowe uznaje się „cześć”, jednakże pozwolę sobie zachować określenie „kult”, nie wikłając się w kwestie terminologicznie sporne.

${ }^{5}$ Należy podkreślić, że termin „akulturacja” nie wyczerpuje charakteru zachodzenia konkretnych zjawisk przy przenikaniu się różnych tradycji religijnych, jakie istniały w przypadku opisywanych przeze mnie przykładów. W tym momencie jednak ograniczę się do tego terminu. 
źródeł wskazujących na dialog religijny, na poziomie religijności ludowej i maryjnej, która w szczególności nas interesuje. Wątki maryjne w historii tych misji obejmowały głównie takie obszary jak dzieła sztuki tworzone i inspirowane przez jezuitów, gdzie dochodziło do dwustronnych inspiracji postaciami Maryi i Guanyin - można jednak powiedzieć, że miały one głównie charakter egalitarny i nie obejmowały sztuki ludowej.

\section{NA KARTACH HISTORIl. NIEBEZPIECZNE ZWIĄZKI}

\subsection{KULT MARYI. HISTORIA NIEPOROZUMIEŃ}

Pomimo niewielu źródeł biblijnych postać Maryi niezwykle szybko znalazła swoje miejsce w świadomości religijnej członków wspólnoty chrześcijańskiej. Faktem niemalże niezaprzeczalnym jest to, że miała w tym udział raczej ludowa i przekazywana ustnie tradycja, jak i zapewne potrzeby religijne chrześcijan. Niekanoniczna Proto-ewangelia Jakuba cieszyła się u początku chrześcijaństwa niezwykłą popularnością, a mało kto decydował się na podważanie jej autorytetu. Z niej to swego czasu można było dowiedzieć się najwięcej na temat postaci Maryi, a dziś ukazuje nam ona, jak ówcześni wierni postrzegali Matkę Jezusa.

Już we wczesnym chrześcijaństwie dochodziło jednak do kwestii spornych i kontrowersji, gdzie głównym przedmiotem była cześć oddawana Maryi. Epifaniusz z Salaminy odnotowuje w dziele Panarion, że kolyrydianki dopuszczały się nadużyć w czci oddawanej Maryi, m.in. poprzez składanie jej ofiar z chleba ${ }^{6}$.

W IV wieku zauważano niebezpieczeństwa łączenia się lokalnych kobiecych kultów z postacią i czcią maryjną ${ }^{7}$. Z jednej strony dochodziło

${ }^{6}$ Zobacz: F. Courth, Teksty teologiczne. Mariologia, red. E. Adamiak, Poznań 2005, s. 77.

7 Trudno wskazać jednoznacznie, jakie były przyczyny owego synkretyzmu, o którym wspomina Epifaniusz. Wydaje się, że był to typowy kult charakterystyczny dla kobiecych stowarzyszeń. Można także zauważyć pewne podobieństwo ze składaniem w ofierze pieczywa i ciast Isztar. Por. G. Widengren, Fenomenologia religii, tłum. J. Białek, Kraków 2008, s. 319. Dokładnie opracował ten temat S. Benko w: The Women Who Sacrificed To Mary: The Kollyridians, w: S. Benko, The Virgin Goddess: Studies in the Pagan and Christian roots of Mariology, Brill 2003. 
do nadużyć i zbytniego wywyższenia postaci Maryi, z drugiej natomiast ganiono postawę, która odrzucała lub zanadto umniejszała wagę czci Maryjnej. Pierwszy najgłośniejszy spór maryjny związany z tytułem Theotokos (Boża Rodzicielka) pomiędzy Nestoriuszem a Cyrylem miał jednak podstawy chrystologiczne.

W następnych wiekach cześć oddawana Maryi we wschodnim, jak i zachodnim chrześcijaństwie wywoływała raczej kontrowersje. Spory pojawiły się w dobie reformacji i od tamtej pory postać Maryi, oraz należna jej cześć, były jednym z ważniejszych punktów spornych pomiędzy Kościołem rzymskim a protestantami ${ }^{8}$. Wiele wyzwań dla mariologii przyniósł wiek XX - od feministycznych interpretacji poczynając, poprzez dążenie do uchwalenia nowego dogmatu maryjnego o pośrednictwie Maryi, po wizje Maryi jako hipostazy Ducha Świętego'.

Po tym krótkim przeglądzie historii idei mariologicznych należy spojrzeć na Kościół „nestoriański”, gdyż jego dzieje są tutaj najbardziej znaczące. Jednakże najpierw trzeba zwrócić uwagę na pewne historyczne spekulacje, które są godne odnotowania. Pomimo ogólnie przyjętego stanowiska, jakoby jingjiao było chrześcijaństwem wywodzącym tradycje z „Kościoła nestoriańskiego”, oraz jego oczywistego pochodzenia z terenów wschodniej Syrii, nie ma niepodważalnej pewności, że była tam w jakimkolwiek stopniu znana nauka Nestoriusza i jego poglądy. Chińskie źródła nie mówią nam nic o Nestoriuszu ${ }^{10}$. Dzięki temu można przypuszczać, że kult Maryi jako Bożej Rodzicielki został przeniesiony przez wiernych do Chin dynastii Tang.

8 Marcin Luter pisał: „Ona niechętnie słucha niepotrzebnych gaduł, którzy wiele kazań głoszą i piszą o Jej zasługach. Oni chcą przez to dowieść swej wielkiej wiedzy i nie dostrzegają, jak osłabiają Magnificat, dowodzą, jakoby Matka Boga kłamała, i umniejszają łaskę Boga”, za: F. Courth, Teksty teologiczne, s. 193.

9 Tak, jak pozycji feministycznych związanych z Maryją ukazało się niezmiernie wiele i ciężko by mi było wskazać co ważniejsze (część zostanie wspomniana dalej), tak w przypadku kolejnych kwestii chciałbym zwrócić szczególną uwagę na apele wysyłane do Stolicy Apostolskiej w celu ustanowienia piątego dogmatu, mówiącego o Współodkupicielce, Pośredniczce łask wszelkich oraz Orędowniczce człowieka oraz na twierdzenia Leonardo Boffa, że „Maryja musi zostać uznana za hipostatycznie złączoną z Trzecią Osobą Trójcy”, F. Courth, Teksty teologiczne, s. 260.

${ }_{10}$ Por. M. Deeg, The "Brilliant Teaching". The Rise and Fall of "Nestorianism" (Jingjiao) in Tang China, "Japanese Religions", vol. 21 (2), s. 92n. 


\subsection{JINGJIAO. CHRZEŚCIJAŃSTWO W PAŃSTWIE ŚRODKA}

W czasie rządów cesarza Taizonga 唐太宗, jak i przez niemal całą dynastię Tang, Chiny były państwem nadzwyczaj otwartym na obce wpływy religijne i kulturowe. Max Deeg nazywa ten okres „Złotą Erą” historii Chin i twierdzi, że w tym czasie nastąpiło apogeum religijnego pluralizmu. Również buddyzm osiągnął szczyt swojego rozkwitu, rozwijając szkoły charakterystyczne dla chińskiej mentalności ${ }^{11}$.

W dynastii Tang były znane również inne „barbarzyńskie nauki” przybyłe z Zachodu, które jednak raczej nie wyszły poza diaspory ${ }^{12}$. Były to: zaratusztrianizm, manicheizm oraz islam (dziś dalej obecny głównie wśród mniejszości chińskich Hui i Ujgurów ${ }^{13}$ ). Nic nie wskazuje jednak na to, by jingjiao było, tak jak reszta religii zachodnich, wyznawane przez zagranicznych kupców. Chrześcijaństwo wydaje się zdecydowanie najbardziej uprzywilejowaną religią zachodnią (poza buddyzmem) w dynastii Tang. Źródła wskazują też na to, iż polityczna i handlowa współpraca z Bizancjum mogła wpłynąć na pozycję chrześcijaństwa ${ }^{14}$.

Najczęstszym określeniem na Asyryjski Kościół (Wschodu) w Chinach jest Jingjiao (景教), które mogło by być przetłumaczone jako „Promienista nauka”, „Olśniewająca nauka” lub „Świetlana religia” (Radiant Teaching, Brilliant Teaching, The Luminous Religion $\left.{ }^{15}\right)^{16}$. Źródła mówią,

11 Por. M. Deeg, The "Brilliant Teaching", s. 94.

12 Por. M. Deeg, The "Brilliant Teaching", s. 95.

13 Zob. A. Berzin, The Situations of Buddhism and Islam, 1996, http://www. berzinarchives.com/web/en /archives/study/islam/modern_interaction/situation_buddhism_islam_china.html (dostęp 20.02.2015).

${ }^{14}$ By dowiedzieć się więcej na ten temat, zob. T. H. Barrett, Buddhism, Taoism and the eighth-century Chinese term for Christianity: a response to recent work by A. Forte and others, „Bulletin of SOAS”, 65 (2002) 3, s. 559-560.

15 Angielskie określenia stosowane w: The Lost Sutras of Jesus. Unlocking the Ancient Wisdom of Xian Monks, red. R. Riegert, T. Moore, Seastone 2003 oraz M. Deeg, The "Brilliant Teaching".

${ }^{16}$ Istnieje jednak wiele teorii odnośnie do tego, jak rzeczywiście było nazywane chrześcijaństwo w Chinach. Istnieje koncepcja, że przed 745 r. chrześcijaństwo było nazywane Bose jiao - „perska nauka”, a następnie Da Qin Jiao - „nauka Wielkiego Qin”, gdzie Wielkie Qin było określeniem stosowanym przez ówczesnych Chińczyków na Zachodnie krainy. Por. T. H. Barrett, Buddhism, Taoism, s. 556. 
że „w dwunastym roku Cheng-Kuan (638 r. n.e.) cesarz Taizong wybudował perską świątynię dla Aluobena (阿羅本), zagranicznego mnicha”17. Jednakże $\mathrm{z}$ napisu za steli $\mathrm{w}$ Xiłan można wnioskować, że nastąpiło to w 635 r. n.e. Sama stela została wzniesiona 4 lutego 781 roku $^{18}$. Religijnym centrum życia ówczesnych chrześcijan była świątynia Da Qin (大秦) w okolicach Lou Guan Dai (które było jednocześnie głównym centrum religijnym taoizmu!). Sama nazwa Da Qin w tym kontekście sprawia, że chrześcijaństwo nie tylko mogło mieć niezwykle uprzywilejowaną pozycję jako religia i nauka (czyli w konsekwencji także dao), gdyż Da Qin (poza określeniem odległych krain Zachodu) wiązało się także z utopijną krainą, ziemskim rajem znajdującym się na Zachód od Chin. Chrześcijaństwo, jako nauka przybyła $\mathrm{z}$ tamtych stron, musiało się pozytywnie jawić taoistom ze względu na samo pochodzenie ${ }^{19}$.

Ówczesne chińskie chrześcijaństwo zdaje się nam ukazywać jako religia niezwykle dobrze zinkulturowana w rzeczywistość ówczesnego imperium dynastii Tang i jego obywateli. Nie jest to religia hermetycznie zamknięta, bojąca się obcych wpływów, usilnie broniąca swojej odrębności i wyłączności. Nie jest to religia przybyszów z barbarzyńskiego Zachodu, zamykających się w gettach i niewchodzących w dialog z ówczesnym społeczeństwem ${ }^{20}$. Wręcz przeciwnie. Jingjiao/„Olśniewająca nauka”, przynajmniej taka, jaką widzimy na kartach Sutr Jezusa znalezionych w Dunhuang i na steli z Changanu (长安)(aktualnie Xian), ukazuje nam niezwykle żywy obraz wiary ówczesnych chrześcijan, nieco różny od tego obecnego na Zachodzie w VII wieku.

17 The Lost Sutras of Jesus, s. 16. Jeśli nie zaznaczono inaczej, wszystkie tłumaczenia są własne.

${ }_{18}$ M. Deeg, The "Brilliant Teaching", s. 92.

19 Por. T. H. Barrett, Buddhism, Taoism, s. 557-558.

${ }^{20}$ Sądzi się jednak, że rodzimych Chińczyków, którzy byli ordynowani, było stosunkowo niewielu. Jednak nawet podchodząc z dozą sceptycyzmu do treści ze steli z Xiłanu, jakoby chrześcijaństwo miało być tak popularną religią w Chinach dynastii Tang, jak to jest tam przedstawione, same Sutry Jezusa wskazują zdecydowanie na żywy i otwarty dialog między chrześcijaństwem, buddyzmem, taoizmem oraz konfucjanizmem. Deeg także stwierdza, że przynajmniej na początku swojej obecności w Chinach wspólnota chrześcijan była pewnego rodzaju diasporą w Stolicy. Por. M. Deeg, The "Brilliant Teaching", s. 94. 
Według świadectw pisanych w 635 r. w Imperialnej Bibliotece zaczęto tłumaczenie pism ${ }^{21}$ sprowadzonych przez Aluobena. Cesarz Taizong zapoznał się z ową „Prawdziwą Nauką” i wydał dekret nakazujący propagowanie jej w 638 roku. Oświadczenie cesarza głosiło, że:

Nie ma jednej nazwy dla Drogi.| Mędrcy nie przybywają pod jedną postacią.| Te Nauki obejmują każdego i mogą zostać przyjęte w każdej krainie.| Mędrzec wielkiej cnoty, Aluoben, przyniósł te pisma z odległej krainy Imperium Qin i podarował je nam w Stolicy.| Studiowaliśmy te pisma i uznaliśmy je za nieziemskie, głębokie i tajemnicze.| Uznaliśmy ich słowa za czyste i wyraźne.| Kontemplowaliśmy narodziny i wzrost tradycji, z której te nauki wyrastają.| Te nauki uratują wszystkie istoty i przyniosą korzyść ludzkości, i jest słuszne, by były praktykowane na całym świecie ${ }^{22}$.

Pisma należące do Jingjiao są pełne buddyjskiej, taoistycznej i konfucjańskiej terminologii, co pokazuje nam, w jaki sposób działała ówczesna wspólnota oraz jak szerzono naukę chrześcijańską.

Co do postaci Maryi w ówczesnym chrześcijaństwie, możemy zdać się jedynie na spekulacje, gdyż brakuje znaczących źródeł tak pisanych, jak i materialnych (choćby wytworów artystycznych). W jednej z sutr z Dunhuang mówiącej o życiu Jezusa jest wspomniana Maryja jako Mo Yen - dziewczyna, na którą został zesłany Chłodny Wiatr (w angielskim tłumaczeniu „Cool Wind”) i wszedł w jej łono, dzięki czemu poczęła bez męża $a^{23}$.

Jedno z najważniejszych dla nas świadectw odnośnie do Maryi i oddawanej jej czci znajduje się we wspomnianej Pagodzie Da Qin, w okolicach Lou Guan Dai. W niej to ma się znajdować przedstawienie Narodzenia Pańskiego. Mimo że przez wieki ten relikt chrześcijaństwa był

${ }^{21}$ Max Deeg zamiast o pełnych tłumaczeniach woli mówić o specjalnych kompilacjach tekstów przeznaczonych dla chińskich czytelników. M. Deeg, The "Brilliant Teaching", s. 94.

${ }^{22}$ The Lost Sutras of Jesus, s. 63. Nie jest to najdoskonalsze tłumaczenie tekstów „nestoriańskich” na angielski, ale oddaje ogólny sens tego, co najistotniejsze - stanowi świadectwo, jak chrześcijanie, zwłaszcza z kolejnych pokoleń od pojawienia się w Chinach zaadaptowali terminologię buddyjską, taoistyczną oraz konfucjańską.

${ }^{23}$ Por. The Lost Sutras of Jesus, s. 116. 
w rękach taoistów, nie zakłada się, by postać ta miała mieć coś wspólnego z ową religią, gdyż zupełnie nie odpowiada jej ikonografii. Jeden ze świadków, który widział tę podobiznę - Rob Gilhooly ${ }^{24}$ - nie wspomina o niej wiele. Dużym problemem jest to, że przez wieki nikt nie restaurował tego budynku i cudem jest, że w ogóle on przetrwał. Na szczęście nie potrzebujemy do późniejszych rozważań dokładnych informacji na temat tej domniemanej podobizny Maryi. Wystarczy nam świadectwo, że taki wizerunek (być może niejeden) istniał.

Chińscy badacze stwierdzili, że podobizna ta przedstawia Guanyin, a napisy na ścianie są w języku tybetańskim (aktualnie przyjmuje się, że jest to syryjskie graffiti). Martin Palmer wysunął własną teorię: mianowicie w momencie kiedy jingjiao rozprzestrzeniało się w Chinach, przyjęty był głównie męski obraz Guanyin. To za dynastii Tang Guanyin zaczęto przedstawiać jako kobietę $\mathrm{z}$ dzieckiem. Zwraca on także uwagę na to, iż owa podobizna Maryi-Guanyin z Da Qin odpowiada ikonograficznie tym wizerunkom Maryi, które znajdują się w Grecji i Rosji, co zupełnie zignorowali chińscy badacze ${ }^{25}$.

Jeśli wzorem Palmera założymy, że faktycznie jingjiao było tak popularne, jak na to wskazują źródła pisane (brak dowodów w postaci ruin i innych reliktów nie może dyskredytować od razu ważności tych tekstów $\left.{ }^{26}\right)$, to można by mówić o rzeczywistym wpływie chrześcijaństwa na kulturę i religię chińską. Stela wspomina o wzniesieniu świątyń w stu miastach pod rządami cesarza Gaozonga (649-683) oraz o tym, że pod rządami cesarza Suzonga (756-762) wzniesiono ponownie świątynie w pięciu prowincjach. Nie znaleziono jednak żadnych dowodów archeologicznych, by potwierdzić ten przekaz ${ }^{27}$. Max Deeg nie podziela jednak optymizmu Palmera co do rzeczywistego wpływu chrześcijaństwa

${ }^{24}$ Relacja na: R. Gilhooly, Signs of The Cross in China, „The Japan Times online”, http://search.japantimes.co.jp/cgi-bin/fv20010724a1.html (dostęp 15.01.2011).

25 Por. R. Gilhooly, Signs of The Cross in China; The Kuan-Yin Chronichles. The Myths and Prophecies of the Chinese Goddess of Compassion, red. M. Palmer, J. Ramsey, Man-Ho Kwok, Charlottesville 2009.

${ }^{26}$ Palmer zakłada też, że w Chinach istniało znacznie więcej miejsc związanych z chrześcijaństwem, miały one być jednak umiejscowione w dużych ośrodkach miejskich, przez co stały się łatwym łupem czystek z IX wieku. Por. The Kuan-Yin Chronichles.

27 Por. M. Deeg, The "Brilliant Teaching", s. 97. 
na pozostałe religie chińskie i buddyzm. Ma wiele zarzutów co do rzetelności jego pracy jako sinologa i nazywa jego postawę „,inkluzywnym hiper-orientalizmem" (jeszcze bardziej krytykuje jednak Saekiego oraz innych chrześcijańskich sinologów dopatrujących się znacznego wpływu chrześcijaństwa na chińskie pisma) ${ }^{28}$. Deeg jest przeciwny inkluzywizmowi uprawianemu przez większość chrześcijańskich badaczy, którzy starają się wykazać, że religie chińskie są bardziej chrześcijańskie niż się początkowo wydają ${ }^{29}$. Pytanie też, na ile sam Deeg odróżnia ich sądy teologiczne od naukowych. Pomijając same kwestie filologiczne i jego cenne uwagi na ich temat, wydaje się, że miesza on te dwa podejścia. To prawda, że Palmer (i Jon Babcock, z którego przekładu tu też korzystam) w tłumaczeniach tzw. Sutr Jezusa nie podchodzą wystarczająco krytycznie do przekładanego tekstu oraz można zarzucić im błędy natury metodologicznej, jednakże jako tłumaczenia, które mają mieć ze swej natury charakter teologiczny (i duchowy), ukazujące uniwersalność chrześcijaństwa oraz wspólne dziedzictwo religii zawierających logoi spermatikoi (okruchy Logosu) oraz ich pozytywną rolę $\mathrm{w}$ historii zbawienia, nie można im tego liczyć jako błędu. Owszem - można uznać, że zbytnia „chrystianizacja” ${ }^{30}$ tekstów z Dunhuang nie przestrzega w pełni zasad hermeneutyki, jednakże traktując te prace jako teologiczne, nie można już podnosić tych samych zarzutów, gdyż z założenia nie mają być one bezstronne naukowo (czyli de facto sekularne).

Pisałem już wcześniej, że w czasie dynastii Tang wypada także zmiana postrzegania Guanyin - chińskiego odpowiednika bodhisattvy Avalokiteśvary. Ze względu na specyfikę postrzegania tej postaci w kulturze i religijności chińskiej pozwolę sobie używać pojęcia bóg/bogini, obok tego bardziej poprawnego doktrynalnie „bodhisattva”. Za czasów dynastii

${ }^{28}$ Zob. tenże, Digging out God from the Rubbish Heap. The Chinese Nestorian Documents and the Ideology of Research. Publikacja konferencyjna dostępna online: http://repository.kulib.kyoto-u.ac.jp/dspace/bitstream/2433/65875/15/12Deeg.pdf (dostęp 20.01.2015).

${ }^{29}$ Por. tenże, The "Brilliant Teaching", s. 167.

${ }^{30}$ Zob. tenże, Towards a New Translation of the Nestorian Documents from the Tang Dynasty, w: Jingjiao. The Church of the East China and Central Asia, red. R. Malek, P. Hofrichter, Institut Monumeta Serica, Sankt Augustin 2006, s. 120. 
Tang amidyzm i koncepcja „Czystej Ziemi” (kraina buddy Amitabhy ${ }^{31}$ ) trafiają do szerszego grona wiernych. Najważniejszym tekstem, który miał z tym związek, była Sutra Lotosü (skt. Saddharma Pundarīka Sūtra, chiń. Fahua jing 法華經). Czysta Ziemia (skt. Sukhavati, chiń. jingtu 净土, jap. jodo) miała znajdować się na Zachodzie, gdzie przebywał też Budda Amitabha $^{33}$. Raj ten jest jednak dostępny nie dla tych, którzy postępują dobrze, lecz głównie tych, którzy „wierzą”, a raczej są oddani praktyce recytacji Sutry Lotosu. W buddyzmie pierwotnym (hinajana - „mały wóz”) „wiara” to saddha ${ }^{34}$. Jest to zaufanie Buddzie oraz jego naukom oraz jeden z etapów do dalszej praktyki buddyjskiej, gdzie wykracza się poza to pojęcie ${ }^{35}$. W Sutrze Lotosu Budda podkreśla naukę o zręcznych środkach tudzież metodach, gdzie nauka jest dostosowywana do kontekstu i słuchaczy, dzięki czemu zanika sprzeczność, a prawda staje się względ$\mathrm{na}^{36}$. Paul Williams zwraca uwagę, że „Budda lub bodhisattva może głosić nawet niebuddyjskie nauki, jeśli służy to dobru istot" ${ }^{37}$. Za dynastii Sui, poprzedzającej Tang, buddyzm tiantai (akcentujący Sutrę Lotosu i naukę o zręcznych środkach) zyskał niezwykłą popularność. Wydaje się jednak, że przy kolejnej dynastii to szkoła huayan (akcentowała naukę Sutry Girlandy Kwiatów, skt. Awatamsaka Sutra, chiń. huayan jing 華嚴經 oraz naukę o przenikaniu się oraz identyczności) zyskała na popularności ${ }^{38}$. Daje to nam znowu wyraźniejszy obraz dynastii Tang jako państwa tolerancyjnego i pluralistycznego religijnie. Za czasów tej dynastii buddyzm kwitnie - przybywa klasztorów, duchownych, wiernych, tłumaczone są duże ilości dzieł ${ }^{39}$. Wydaje się ostatecznie, że twierdzenie „prawda jest

${ }^{31}$ Sanskryt: Amitabha („Niezmierzona Jasność”), Amitayus („Nieskończone Życie”). Por. H. Nakamura, Pure Land Buddhism and Western Christianity Compared: A Quest for Common Roots of their Universality, „International Journal for Philosophy of Religion” 1 (1970) 2, s. 82. W innych językach: chiń. Amituo Fo 阿爾陀佛, jap. Amida.

32 Znaczna część tekstu powstała w II wieku n.e. Por. P. Williams, Buddyzm Mahajana, tłum. H. Smagacz, Kraków 2000, s. 178.

${ }^{33}$ Por. H. Nakamura, Pure Land Buddhism, s. 82-83.

${ }_{34}$ Por. G. Widengren, Fenomenologia religii, s. 213.

35 G. Widengren, Fenomenologia religii, s. 213.

${ }^{36}$ Por. P. Williams, Buddyzm, s. 180.

37 P. Williams, Buddyzm, s. 180.

38 Por. P. Williams, Buddyzm, s. 195.

39 Por. P. Williams, Buddyzm, s. 151-152. 
względna" stanowi jeden z najważniejszych punktów charakterystyki chińskiej mentalności.

Guanyin („ten/ta który/a odbiera dźwięki”) pojawia się jako tłumaczenie imienia Avalokiteśvara początkowo w Sutrze Lotosu, a potem w Sutrze Serca (skt. Prajñāpāramitā Hrdaya, chiń. Bore boluomi duo xinjing 般若波羅蜜多心經). Nie była to jednak postać stricte kobieca, aczkolwiek pod tą postacią mogła się pojawiać. We wczesnym buddyzmie (a w niektórych szkołach do dzisiaj) płeć męska była uważana za „doskonalszą" i bardziej oświeconą. Zmieni się to częściowo już w okresie władzy cesarzowej Wu. Avalokiteśvara był jednym z dwóch bodhisattvów prowadzących zmarłego przed oblicze Amitabhy. Często przedstawia się go w ikonografii razem $\mathrm{z}$ Amitabhą, a czasem nazywany jest jego emanacją ${ }^{40}$. Wzywanie imienia Avalokiteśvara (Guanyin) miało zapewnić troskę i opiekę tego bodhisattvy wiernemu ${ }^{41}$. Avalokiteśvara dopiero zaadaptowany do kultury chińskiej pod postacią Guanyin zaczął przyjmować częściej kobiecą formę. Jednym z pierwszych i najbardziej popularnym przekładem Sutry Lotosu jest ten dokonany przez Kumarajivę i jego zespół w 406 roku $^{42}$. W tym tłumaczeniu przyjęto formułę Guan 觀(odbierać)-shi 世(świat)-yin 音(dźwięk/i) ${ }^{43}$, które jednak było znane wcześniej. Guanyin (chiń. uproszczony观音) zostało jednak przyjęte jako bardziej dokładne tłumaczenie ${ }^{44}$. Paul Williams za D. T. Suzukim stwierdza, że męskie przedstawienie bodhisattvy Avalokiteśvary jest wersją „doktrynalną”, natomiast żeńskie „popularną"45. Źródła z 668 roku mówią nam, że Guanyin pierwszy raz pojawiła się jako kobieta w 479 roku, by uwolnić swojego wyznawcę $\mathrm{z}$ niewolii ${ }^{46}$. Także piątego wieku sięgają pierwsze kobiece przedstawienia Guanyin ${ }^{47}$. Jak jednak wcześniej zostało

40 Por.P. Williams, Buddyzm, s. 282

${ }^{41}$ Por.P. Williams, Buddyzm, s. 280.

42 Por. P. Williams, Buddyzm, s. 179.

${ }^{43}$ Por. Chün-Fang Yü, Kuan-Yin: The Chinese Transformation of Avalokitesvara, New York 2001, s. 149. Znaki chińskie zostały dodane przez autora.

${ }^{44} \mathrm{~W}$ kwestii niuansów związanych z tłumaczeniem zob. Chün-Fang Yü, Kuan-Yin, s. 148.

${ }^{45}$ Por. P. Williams, Buddyzm, s. 284

${ }^{46}$ Por. Chün-Fang Yü, Kuan-Yin, s. 151.

47 Por. Chün-Fang Yü, Kuan-Yin, s. 151. 
podkreślone, Palmer widzi spopularyzowanie kobiecej formy Guanyin w czasie dynastii Tang, a dokładniej w czasie obecności w Chinach jako przesłankę, że chrześcijaństwo mogło mieć w tym swój niemały udział. To, co szczególnie zwraca uwagę, to przeważająca popularność Guanyin jako „Bogini Miłosierdzia” raczej niż „bodhisattvy współczucia”. Chün-Fang Yü pisze, że to

bóstwo przeszło zasadniczą przemianę gdzieś w okolicach dziesiątego wieku, a w szesnastym wieku Guanyin stała się nie tylko całkowicie chińską, ale także najbardziej uwielbianą „Boginią Miłosierdzia” [oryginalnie jezuicki termin na nią]. Ze wszystkich importowanych bóstw Guanyin jest jedynym, któremu udało się stać oryginalną chińską boginią. Tak bardzo, że nawet niektórzy Chińczycy, którzy nie są zaznajomieni z buddyzmem, nawet nie są świadomi jej buddyjskiego pochodzenia ${ }^{48}$.

Co się stało z jingjiao i jego spuścizną religijną i kulturową, świadectwem dynamicznej misji oraz wysiłków zmierzających do jak najlepszego zaadaptowania nauki chrześcijańskiej w Chinach? Dla Maxa Deega jest jasne, że wszystkie wspólnoty chrześcijańskie zniknęły najprawdopodobniej w latach 843-845, kiedy to też zakazano nauczania buddyzmu oraz innych religii rodzimie nie-chińskich. Nie przetrwały żadne wspólnoty, tak jak się to stało $\mathrm{w}$ przypadku kakure kirishitan $\mathrm{w}$ Japonii ${ }^{49}$. To, co zostało po jingjiao, to jeszcze tajemnicze, nieliczne relikty i nie zawsze jednoznacznie zrozumiałe teksty, na podstawie których ciężko wyobrazić sobie faktyczne działanie wspólnoty. Najbardziej prawdopodobna koncepcja jest taka, że chrześcijaństwo zbytnio się zsinizowało i w ostatnim etapie istnienia zatraciło świadomość swej wyjątkowości. Mogło by to tłumaczyć, dlaczego zniknęło w tym samym czasie, co buddyzm. Czy jednak można mówić o szczególnie znaczących wpływach doktryn chrześcijańskich na religie chińskie? Odpowiedź na to pytanie też wydaje się w tym momencie dość niejednoznaczna. Zapewne to raczej wspólnota chrześcijańska w dużej mierze czerpała z tradycji chińskiej, dzięki czemu łatwo się zaadaptowała

${ }^{48}$ Chün-Fang Yü, Kuan-Yin, s. 223-224, za: D. L. Overmyer, Review: Kuan-yin: The Development and Transformation of a Chinese Goddess, „The Journal of Religion”, 82 (2002) 3, s. 420.

${ }^{49}$ Por. M. Deeg, The "Brilliant Teaching", s. 105. 
i mogła swobodnie funkcjonować, prowadząc dialog np. z buddystami. Jednak nie można jednoznacznie ocenić, w jakim stopniu przedstawienia Matki Bożej mogły wpłynąć na postrzeganie Guanyin. Istnieją bardzo rozbieżne opinie na ten temat, tak pozytywne, jak i negatywne.

\subsection{Z SALONÓW POD ZIEMIĘ. CHRZEŚCIJAŃSTWO W JAPONII}

- Gdy przybyliście, panie, do tego kraju, wszędzie budowano tu kościoły, wiara pachniała jak świeży kwiat o poranku, a Japończycy tłumnie przyjmowali chrzest, spieszac jedni przed drugimi, jak Żydzi nad Jordanem.

- A jeśli bóstwo, w które wówczas wierzyli Japończycy, nie było Bogiem chrześcijańskim? - wyszeptał powoli Perreyra ${ }^{50}$.

Pierwszy edykt antychrześcijański był wydany w 1587 r. przez Tokugawę Hideyoshiego, aczkolwiek nie był on surowo przestrzegany. Głosił on, że „Japonia jest krajem bogów, ale otrzymuje fałszywe nauki od chrześcijańskich państw" oraz że należy zaprzestać tolerowania tego zwyczaju. Kolejny, surowszy, edykt wydany został już przez Tokugawę Ieyasu i wszedł w życie w 1614 r., a nastąpiło to po wielu latach działania dobrze prosperujących ${ }^{51}$ misji katolickiej w tym kraju. Wiązało się to też z ogólnym obostrzeniem przepisów migracyjnych w samej Japonii. W 1629 r. wprowadzono zwyczaj ebumi ${ }^{52}$. Od tego czasu gigantyczna liczba już ochrzczonych chrześcijan musiała „zejść pod ziemię”. Bardzo często byli to ludzie należący do biedoty, szczególnie żyjący z rybołówstwa i upra-

50 S. Endo, Milczenie, tłum. I. Denysko, Warszawa 1986, s. 132.

${ }^{51}$ Pisząc to, mam jednak świadomość tego, że formacja duchowa nowo nawróconych była bardzo słaba, żeby nie powiedzieć, że czasem jej niemal zupełnie nie było. Godny odnotowania jest jednak fakt, że do 1614 r. chrześcijanie stanowili ok. 2\% społeczeństwa japońskiego. Peter Nosco pisze, że dzięki temu, że pojawiały się już wcześniej pewne trudności w misji, misje zostały zorganizowane w ten sposób, że ułatwiło to późniejsze organizowanie się chrześcijan w ukryte i zorganizowane grupy. Zob. P. Nosco, Secrecy and the Transmission of Tradition. Issues on the Study of "Underground" Christians, „Japanese Journal of Religious Studies” 20 (1993) 1, s. 3-29.

${ }^{52}$ Deptanie plakietki, deski z podobizną Jezusa lub Maryi jako znak wyrzeknięcia się wiary czy braku przynależności do religii chrześcijańskiej. Por. C. Whelan, Religion Concealed. The Kakure Kirishitan on Narushima, „Monumenta Nipponica”, 47 (1992) 3, s. 370 . 
wy roli, jednakże nierzadko należeli do niej też samurajowie. W $1637 \mathrm{r}$. w buncie chłopskim w Shimabara, w którym dominowali chrześcijanie, niemal całe dwadzieścia tysięcy buntowników zostało zabitych ${ }^{53}$. W 1639 r. Japonia już się całkowicie zamknęła. Chrześcijanie przetrwali głównie na izolowanych terenach, zwłaszcza w okolicach dzisiejszej prefektury Nagasaki i na pobliskich wysepkach ${ }^{54}$. W powieści Milczenie autorstwa Shusaku Endo możemy ujrzeć spokojnych japońskich chłopów, o dobrotliwym uśmiechu i prostym stylu życia, którzy są w stanie przejść w imieniu swojej wiary największe tortury i nieraz okazują się wytrzymalsi od swoich duchownych przewodników, misjonarzy. Możliwe, że coś w tym obrazie było z prawdy, skoro część japońskich chrześcijan przetrwała najgorsze lata prześladowań ${ }^{55} \mathrm{i} \mathrm{w}$ pewnej postaci ich tradycja przetrwała do dzisiaj. Owi ukryci chrześcijanie (kakure kirishitan - 隠れキリシタン) podtrzymywali swą wiarę i wierzenia przez lata bez odpowiedniej formacji duszpasterskiej, sakramentów i pomocy od strony duchownych. Dla nas dzisiaj ich religia może się wydawać bardziej japońska niż chrześcijańska, będąc zlepkiem różnych doktryn i zwyczajów. Trzeba jednak zauważyć, że nie mieli oni żadnej możliwości podtrzymania wiary chrześcijańskiej w jej ortodoksyjnej katolickiej formie, a i tak jest cudem, że nie ulegli wytępieniu. Tym, co mogło się przyczynić do synkretyzmu chrześcijaństwa i rodzimych religii Japonii jest też fakt, że na ok. 300000 wiernych nigdy nie przypadało więcej niż 137 księży, a i przygotowania do chrztu nie były wystarczające, by przekazać zawiłości chrześcijańskiej doktryny ${ }^{56}$.

${ }^{53}$ Por. C. Andressen, Krótka historia Japonii. Od samurajów do Sony, Warszawa 2004, s. 63.

${ }^{54}$ Np. na wyspach Gotō, gdzie kakure przetrwali do dzisiaj. Por. C. Whelan, Religion Concealed, s. 369-387. Większe skupiska kakure znajdowały się też na wyspach Ikitsuki, Hirado i w okolicach Sotome. Por. A. M. Harrington, The Kakure Kirishitan and Their Place in Japan's Religious Tradition, „Japanese Journal of Religious Studies” 7 (1980) 4, s. 319.

${ }_{55}$ Pierwsza polska publikacja na temat męczeństwa chrześcijan w Japonii o wiele mówiącym tytule: Widok stateczności Iapońskiey przez która sto osmnascie zacnych męczenników okrutnymi metami dla Iezusa Chrystusa zamordowani przez miecz, ogień $y$ wodę korony chwały nieśmiertelney dostąpili ukazała się drukiem już w XVII wieku (Poznań 1622).

56 Por. The Beginning of Heaven and Earth. The Sacred Book of Japan Hidden Christians, tłum. C. Whelan, University of Hawaii 1996, s. 11. 
To, co pomogło w jednoczeniu i organizacji chrześcijańskich wspólnot, to świeckie funkcje dōjuku i kanbō, których do 1604 r. było w Japonii ponad $400^{57}$. Po otwarciu się Japonii wielu kakure przeszło na katolicyzm, ale są jeszcze tacy, którzy dalej utrzymują stare zwyczaje. O. Bernard Petitjean po „odkryciu” ukrytych chrześcijan ${ }^{58}$ w XIX w. był jednak pod wrażeniem znajomości katolickiej teologii przez kakure: wiedzieli bowiem o Trójcy, Upadku, Wcieleniu i Dziesięciu Przykazaniach ${ }^{59}$.

Większość z tekstów kakure nie przetrwała do dzisiaj, a część $\mathrm{z}$ tych, które przetrwały, nie jest nawet znana dzisiejszym kakure. Peter Nosco zauważa, że nie jest prawidłowością, by tajne stowarzyszenia religijne posiadały źródła pisane, a kakure posiadało ich sporo, zwłaszcza dlatego, że modlitwy chrześcijańskie były dla Japończyków długie i ciężkie do nauczenia, ze względu na to, iż często były przekazywane w języku portugalskim czy po łacinie ${ }^{60}$. Na przykład modlitwa Ave Maria była znana przede wszystkim $\mathrm{w}$ formie łacińskiej, przez co z czasem zatraciła swoje oryginalne brzmienie i przede wszystkim znaczenie, gdyż była przekazywana $\mathrm{z}$ pokolenia na pokolenie jedynie $\mathrm{w}$ formie ustnej ${ }^{61}$. Po zapoznaniu się z tekstami kakure, ich wierzeniami i wiarą można zauważyć, że postać Maryi zajmuje szczególne, niemal centralne miejsce.

De facto jedynym tekstem religijnym, nie licząc orashio (modlitw) i kalendarzy kakure kirishitan, jest Tenchi hajimari no koto (O poczatkach nieba i ziemi). Do dzisiaj znaleziono dziesięć jego kopii, lecz nikt ze współczesnych kakure z wysp Goto nawet o nim nie słyszał ${ }^{62}$. Natomiast jeszcze w 1931 r. dziewięćdziesięciojednoletni mężczyzna z Sotome wyrecytował z pamięci całe Tenchi hajimari no koto Tagicie Koyi ${ }^{63}$. Jako pierwszy jednak

57 Por. P. Nosco, Secrecy and the Transmission, s. 5-8.

${ }^{58} \mathrm{Ci}$, którzy nie przyłączyli się do Kościoła katolickiego po otwarciu się Japonii, są nazywanie hanare kirishitan - odłączeni chrześcijanie.

59 Por. The Beginning, s. 14.

${ }^{60}$ Por. P. Nosco, Secrecy and the Transmission, s. 12.

${ }^{61}$ P. Nosco w swojej pracy porównał oryginalną łacińską wersję Ave Maria z wersjami z Ikitsuki i Gotō, wykazując różnice, jakie zaszły w przekazie fonetycznym. P. Nosco, Secrecy and the Transmission, s. 20.

${ }^{62}$ The Beginning, s. 16.

${ }^{63}$ Tagita Koya był pierwszym badaczem, któremu udało się zebrać kopie Tenchi hajimari no koto w celach badawczych. Por. The Beginning, s. 16. 
spotkał się z ową „biblią” w formie pisanej biskup Bernard Petitjean 14 kwietnia 1865 r., jednakże ten egzemplarz zaginął ${ }^{64}$. Wiadomo więc, że ów tekst był przekazywany w tradycji ustnej, jak i w formie pisemnej ${ }^{65}$. Ciężko jednak stwierdzić, kiedy dokładnie mógł powstać. Ze względu na jego synkretyczny charakter należałoby przyjąć, że musiał powstać w okresie nasilających się prześladowań, możliwe, że z inicjatywy „starszych”66 wśród kakure. Najstarszy z istniejących egzemplarzy pochodzi z 1827 roku $^{67}$. Tekst ten jest pewną próbą rekonstrukcji doktryny chrześcijańskiej poprzez wtórną interpretację zachowanych rytów, rytuałów, zwyczajów oraz modlitw, jak i niewielkich ilości treści teologicznych.

Tenchi hajimari no koto nie jest tak znanym tekstem jak wymienione wcześniej Sutry Jezusa. Wydaje się, że ze względu na swoją treść nie szokuje w taki sposób i nie wydaje się, by miał dla zachodnich czytelników głębsze teologiczne i filozoficzne znaczenie. Można powiedzieć, że jest on pomostem pomiędzy rodzimymi wierzeniami XVII-wiecznej Japonii i ludową wersją chrześcijaństwa. Sprawia to jednak, że tekst ten jest mało interesujący dla większości potencjalnych zachodnich odbiorców, którzy poszukują duchowych inspiracji, potrafiących w świecie pluralizmu religijnego pogodzić treści chrześcijaństwa, oraz coraz bardziej popularnego buddyzmu i taoizmu filozoficznego (co się udaje Sutrom Jezusa). Te dwa oblicza chrześcijaństwa kirishitan oraz jingjiao, oba z dalekich rejonów Azji, prezentują się zupełnie inaczej. I wydaje się, że ich teksty religijne bardzo dobrze to oddają. Wśród niewielu istniejących przekładów jest jeden w języku polskim autorstwa Wojciecha J. Nowaka, z którego będę korzystał w dalszej części pracy.

Maryja (w wersji kakure - Maruya) w Tenchi hajimari no koto pojawia się znacznie częściej niż na kartach Ewangelii, a jej rola na pewno nie ustępuje Jezusowi. To na jej dzieje kirishitan zwracali i zwracają szczególną uwagę. U późniejszych kirishitan i tych współczesnych (kakure,

${ }^{64}$ Zob. S. Turnbull, The Kakure Kirishitan of Japan, A study of their development, beliefs and rituals to the present day, Richmond 1998, s. 21; The Beginning, s. 13.

${ }_{65}$ Por. P. Nosco, Secrecy and the Transmission, s. 13.

${ }^{66}$ Kakure w różnych regionach Kyushu posiadali różne organa przewodzące grupie wiernych o różnorakich funkcjach, które zastąpiły pierwotne funkcje dōjuku i kanbō.

${ }^{67}$ H. Kawai, The Transformation of Biblical Myths in Japan, „Diogenes” 42/1 (1994) 165, s. 51. 
zwanych przez misjonarzy w XIX wieku hanare - odłączeni) kult Maryi jest jeszcze bardziej podkreślany, a o Chrystusie niewiele wiadomo poza kilkoma przekazanymi wierzeniami, stanowiącymi ważny element doktryny, jednak bez pogłębionej refleksji na ten temat.

Maruya w Tenchi hajimari no koto to prosta dziewczyna pochodząca z gminu, która już w wieku dwunastu lat posiadała dużą wiedzę. Przez cały czas rozmyślała nad swoim zbawieniem, aż zstąpił anioł, który polecił jej trwanie $\mathrm{w}$ cnocie dziewictwa. Ona natomiast padła na ziemię i oddała cześć, skąd wzięła się praktyka odmawiania „modlitwy dwunastu"68. Maruya została przeznaczona do poślubienia króla, jednakże ze względu na swoje śluby nie wyraża na to zgody. Odznacza się w dialogach niespotykaną bystrością, mądrością i pobożnością. Można zobaczyć wręcz analogie do postawy Jezusa z Ewangelii: „Królewska ranga nie przewyższa mojej i jest chwałą tylko na tym świecie. Ten świat jest tylko chwilowym schronieniem. Tylko zbawienie w świecie przyszłym jest ważne" ${ }^{69}$. Maruya dokonuje także wielu cudów: za życia wstępuje do Najwyższego Nieba, a Bóg - Deusu nadaje jej rangę „Świętej Maruyi Śnieżnej"70. Następnie widzimy głównie losy Maruyi błąkającej się po ziemi, brzemienną z Ommi (Jezus) i wygnaną przez rodziców. W tekście też widzimy polemikę z nauką Czystej Krainy Buddy, w postaci nawrócenia przez Ommi (Jezusa) mnicha Gakujuran, który miał znać wszystkie sutry

${ }^{68}$ Wojciech J. Nowak twierdzi, że był to zapoczątkowany przez franciszkanów zwyczaj odmawiania Abe Maria (Ave Maria) dwanaście razy w Wigilię Bożego Narodzenia. Por. Tenchi hajimari no koto (O poczatkach nieba i ziemi), tłum. W. J. Nowak, „Silva Iaponicorum", FASC. XV, Spring 2008, s. 42 i n. Nowak prawdopodobnie przejął ten pogląd za Christal Whelan lub od Ebisawy (na którego powoływała się Whelan), czego W.J. Nowak nie odnotował w komentarzu. Nosco wspomina z kolei o innym zwyczaju 33-krotnym odmawianiu Garasa (Zdrowaś Mario, lecz nie po łacinie) w dzień przed i w dniu święta Bożego Narodzenia. (por. P. Nosco, Secrecy and the Transmission, s. 17). Różnice w zwyczajach mają swe podstawy zapewne w różnych programach misjonarskich zakonów. Natomiast czytając relacje Whelan, można zauważyć, że odmawianie Abe Maria (Ave Maria) 33 lub 12 razy było niezwykle często spotykane wśród kakure z Narushimy. Zob. C. Whelan, Religion Concealed, s. 374.

${ }^{69}$ Tenchi hajimari no koto, s. 43.

70 Tamże, s. 44. Dnia 4 sierpnia obchodzone jest święto Yuki no Santa Maria (Świętej Marii od Śniegu). Zob. C. Whelan, Religion Concealed, s. 374. 
i nauczać o buddzie Amidzie ${ }^{71}$. Dalej przedstawione są dzieje Jezusa, aż po Pasję, śmierć i zmartwychwstanie. W części O credo (Kirinto no koto) można przeczytać, że:

Matka Maruya, usłyszawszy głos z nieba, wstąpiła do nieba trzeciego dnia siódmego miesiąca $\mathrm{z}$ góry Oribetan. $\mathrm{W}$ niebie matka pełniła rolę pośrednika, Ommi - zbawiciela, Deusu był Ojcem, Ommi Hiriyo - Synem, a Maruya - Duchem Świętym. I tak stanowili Trójcę Świętą. Mimo że byli w trzech osobach, stanowili jedno ciało ${ }^{72}$.

Widać więc, że rola, którą przypisano Maryi, znacznie przewyższa tę, którą ma w Kościele katolickim (chociaż nie wydaje się daleko odbiegać od teologicznych propozycji wysuwanych przez np. wspomnianego na początku Leonardo Boffa). Pomimo tych niekiedy znaczących różnic biskup Petitjean skomentował Tenchi hajimari no koto w ten sposób: „Znaleźliśmy tam kilka błędów, ale były one niewielkiej wagi”73. Zwracając uwagę na sam schemat, strukturę narracji o Maryi, można zauważyć, że przypomina ona popularne i charakterystyczne dla średniowiecznego buddyzmu opowieści o apoteozie prostych, ale pobożnych dziewczyn.

Według Christal Whelan postać Maryi w Tenchi jest „Wielką Matką i szamanem. Wpasowuje się $\mathrm{w}$ pozornie przeciwstawne i archaiczne wzorce «dziewictwa-płodności». Nie jest więc dziwne, że Maryja jest najsilniejszą i najbardziej rozwiniętą postacią Tenchi" ${ }^{\prime 4}$. Teoria Whelan, aczkolwiek miejscami nadinterpretowana ${ }^{75}$, wpisuje się w dyskurs związany z kobiecym charakterem rodzimych religii japońskich, co jest bardzo

${ }^{71}$ Por. C. Whelan, Religion Concealed, s. 50.

72 Tenchi hajimari no koto, s. 58.

${ }^{73}$ Por. The Beginning, s. 14.

74 The Beginning, s. 32.

${ }^{75}$ Chodzi przede wszystkim o zbyt mało krytyczne podpinanie kobiecych kultów religijny pod kult Wielkiej Matki. Należy odróżnić konkretne wierzenia i praktyki, niekoniecznie przyjmując najprostsze wytłumaczenie, jakim jest teoria archetypów. Krytykę takiego stanowiska i rzetelne opracowanie kultów kobiecych, które często się wpisuje $\mathrm{w}$ ten dyskurs bogini matki, można znaleźć w: Goddesses Who Rule, red. E. Benard, B. Moon, New York 2000. 
widoczne w twórczości cytowanego we wstępie rozdziału Shusaku Endo i w jego pracach naukowych ${ }^{76}$.

Święto Bożego Narodzenia było bardziej nastawione na oddawanie czci Maryi niż celebrowanie narodzin Chrystusa. Whelan pisze, że w Narushimie On-Haha Santa Maria Sama zajmowała zdecydowanie centralne miejsce kultu tego dnia (w przypadku Narushimy był to 23 grudnia) ${ }^{77}$. Same zwyczaje dotyczące obchodzenia tego święta zawierały elementy miejscowych matsuri ${ }^{78}$. Nie powinno to jednak dziwić nas, którzy także w wigilię Bożego Narodzenia zachowujemy elementy starych ludowych, jeszcze przedchrześcijańskich, jednak już przez tyle lat „ochrzczonych” tradycji.

Ann Harrington pisze o przedmiotach kultu istniejących w środowiskach kakure zwanych nandogami („bóstwa szafy”) lub nando-sama. Dzieliły się one na sześć kategorii. Do pierwszej kategorii, czyli gozensama, należały w znacznej mierze przedmioty podarowane przez misjonarzy lub przypominające je, jak wyobrażenia Chrystusa, Matki Bożej, męczenników itp $^{79}$. Mogły to być zwoje i posążki. Były one najczęściej upozorowane na przedmioty zwykłego użytku czy legalne przedmioty czci religijnej (niezabronione w czasie rządów Tokugawa).

${ }^{76}$ Chodzi o jego podział na religie ojcowskie (o charakterze patriarchalnym) chichi no shukyo oraz matczyne haha no shukyo. W jego koncepcji religie Japonii charakteryzuje to, że są to religie matczyne. W spotkaniu z chrześcijaństwem ludność japońska musiała dokonać „umatczynienia” tej religii. Dlatego też skupiono się na bardziej kobiecych (jak uważa) elementach: irracjonalność, miłość, miłosierdzie, opiekuńczość itp. Zob. J.T. Netland, From Cultural Alterity to Habitations the of Grace: The Evolving Moral Topography of Endo's Mudswamp Trope, „Christianity and Literature” 59 (2009) 1, s. 27-48.

77 Por. C. Whelan, Religion Concealed, s. 375. Z kolei bp Petitjean dowiedział się od chrześcijan z Urakami, że obchodzą Boże Narodzenie 25 dnia miesiąca mrozu, a Kichizō, pełniący funkcję chōkata (przywódcy) wyznał, że obchodzą narodziny Riusu przez Santa Maria w dni przesilenia zimowego. Por. P. Nosco, Secrecy and the Transmission, s. 16-17.

${ }^{78}$ Por. P. Nosco, Secrecy and the Transmission, s. 17. Matsuri to popularne święta ludowe, będące świętami okresowymi, związane zazwyczaj z jakimś lokalnym miejscem kultu. Na wyspie Ikitsuki, na zachód od Goto jest wiele matsuri, które wiążą ze sobą święta sintoistyczne z kultem miejsc śmierci chrześcijańskich męczenników. Zob. S. Turnbull, The Kakure Kirishitan of Japan. A study of their development, beliefs and rituals to the present day; tenże, Mass or Matsuri?: The Oyashiki-Sama Ceremony on Ikitsuki, „Monumenta Nipponica” 50 (1995) 2, s. 170-189.

79 Por. A. M. Harrington, The Kakure Kirishitan, s. 319. 
Ze względu na ukryty charakter chrześcijaństwa musiano uciekać się do sprytnych zabiegów, które nie wyjawiłyby wyznawanej religii, pozwalałyby zachować pozory, a jednocześnie, do pewnego stopnia, jawnie dopełniać pewnych praktyk religijnych. Akurat kontekst religijny i kulturowy pozwolił kakure niemal jawnie oddawać cześć Maryi. Postać Koyasu Kannon, czyli Kannon z dzieckiem idealnie się nadawała do przemycania chrześcijańskiej czci dla Matki Bożej. Zresztą kakure nie byli jedynymi, którzy dostrzegali to podobieństwo.

To, w jaki sposób Maria i Kannon były postrzegane i identyfikowane ze sobą, świetnie ilustruje historia przytoczona przez Petera Nosco, a opowiedziana przez japońskiego tłumacza prowadzącego pewnego Holendra do Edo:

Jūhyoe eskortował Holendra do Edo. Pewnego dnia, gdy byli z Holendrem gdzieś w połowie drogi, napotkali buddyjskiego pielgrzyma, który miał na swoich plecach figurkę Koyasu Kannon [Kannon z dzieckiem] i zdziwiony Holender zapytał „Czy to bóstwo też jest czczone w Japonii?”. Kiedy Narabayashi wytłumaczył, że to była buddyjska figura nazywana Koyasu Kannon, Holender odparł, że ta religijna figura również przedstawia założyciela jego religii, Makude Mariya (sic! $)^{80}$.

Ze względu na to niezwykłe podobieństwo kakure wykorzystywali figurki Kannon, tyle że z pewnym charakterystycznym znaczącym elementem, który wskazywałby na chrześcijański charakter owej podobizny. Mógł to być krzyżyk z tyłu czy na spodzie figurki, czy też Kannon mogła mieć krzyż wiszący na szyi. Ta drobna różnica pozwalała kakure zachować swoją tożsamość. Tak zwane figurki Maria-Kannon (nazwa ta nie była używana nigdy przez samych kakure ${ }^{81}$ ) pozwoliły niemalże publicznie uczestniczyć kakure w ich religijnym kulcie, nie przejmując się zbytnio ujawnieniem swojego wyznania i narażeniem na prześladowania. Oprócz figurek wykorzystywano także zwoje z przedstawieniami Matki Bożej, które na pozór wyglądały jak Kannon z dzieckiem. Jak bardzo pobożność maryjna zajmowała centralne miejsce u kakure, ukazuje nam jedno z pierwszych zdań wypowiedzianych przez „ujawniających się” kakure

80 Za: P. Nosco, Secrecy and the Transmission, s. 14.

${ }^{81}$ Por. P. Nosco, Secrecy and the Transmission, s. 13. 
biskupowi Petitjeanowi w pamiętnym dniu 17 marca 1865 r.: „Gdzie jest figura Maria-sama?"82.

Wskazując na charakterystykę kultu maryjnego u kirishitan, należy zwrócić uwagę na to, iż zostały zachowane i podkreślone treści religijne mające znaczenie przede wszystkim wśród społeczności ludowych, agrarnych - płodność, opieka nad kobietami w ciąży i pomaganie przy porodzie. Można również wykazać, że wśród tych pierwotnie chrześcijańskich wspólnot zachodził od początku proces synkretyzacji, będący wynikiem słabej katechizacji nowo ochrzczonych. Słaba znajomość doktryny katolickiej u samych podstaw formacji chrześcijańskiej spowodowała proces znany jako indygenizacja, który w przeciwieństwie do akomodacji jest procesem oddolnym, dokonującym się niejako automatycznie, na poziomie wiernych przyjmujących określone wierzenia i wpisując je w pewien określony, własny system światopoglądowy. W tym wypadku byłby to charakterystyczny dla Japonii, a opisywany przez Hajime Nakamurę pluralizm religijny, który w epoce Edo sprowadzał się do reguły honji-sujiaku, polegającej na nadrzędnej roli kosmologii buddyjskiej, do której mogły zostać podpięte wierzenia sintoistyczne. W tym wypadku japońskie kami byłyby manifestacjami pierwotnie buddyjskich postaci - buddów i bodhisattvów.

Gdyby uznać wcześniejszą, optymistyczną tezę Palmera, jakoby kult Maryi wpłynął na to, jak przedstawiana była Guanyin (Kannon), można by powiedzieć, że historia zatoczyła w tym momencie pewien krąg. Widziałbym jednak taką interpretację jako życzeniową, bardziej o wartości poetyckiej niż merytorycznej. Owe wybrane zagadnienia mogą mieć wartość w podejściu teologicznym, historiozbawczym, lecz w tym momencie wykraczają poza czysto komparatystyczne i historyczne spekulacje. Jakkolwiek wartości naukowej takie spekulacje nie mają, przedstawienia Maria-Kannon przebiły się do świadomości wielu dzisiejszych chrześcijan i buddystów i stały się świadectwem pewnej koegzystencji i żywego dialogu międzyreligijnego ${ }^{83}$.

${ }^{82}$ Por. The Beginning, s. 13.

${ }^{83}$ Chociaż odchodząc znowu od tak pozytywnej interpretacji, należy przyznać, że konieczność adaptacji japońskich chrześcijan, ukrywania swojej religijności i posługiwania się elementami dominującej religii w celu uniknięcia prześladowań ciężko porównywać do dobrowolnego dialogu międzyreligijnego, inkulturacji i wypływających ze szczerych chęci dialogu, współpracy i dzielenia się doświadczeniem wiary. 


\section{ZAKOŃCZENIE}

Zdaję sobie sprawę, że to opracowanie nie oddaje w pełni zawiłości i złożoności problemu, jakim jest związek Marii i Guanyin (Kannon) w przypadku jingjiao i kakure kirishitan. Przybliżając jednak polskiemu czytelnikowi owe unikalne przykłady, chciałbym zwrócić uwagę na nie jako pewne możliwe mariologiczne locus dialogu chrześcijaństwa z religiami Azji Wschodniej. Jeśli prawdą miałyby być wnioski Palmera (w co wprawdzie wątpię), że kobiecy kult Guanyin (Kannon) jest pochodzenia chrześcijańskiego, lub przynajmniej w pewnym stopniu wpłynął na niego $^{84}$, należałoby się zastanowić nad teologicznymi konsekwencjami takiej sytuacji. Nawet jeśli odrzucimy ową propozycję jako nieuzasadnioną, co w świetle aktualnych badań nad źródłami „nestoriańskimi” byłoby zrozumiałe, to pewne pytania natury teologicznej same się nasuwają. Jakie miejsce $\mathrm{w}$ ekonomii zbawczej mają takie (synkretyzm późniego jingjiao i kakure kirishitan) wierzenia? Czy mają one jedynie wartość, o ile przyczyniają się do przyjęcia wiary katolickiej z pobożnością maryjną? Czy wręcz przeciwnie - takie wierzenia mają wartość samą w sobie, jednakże ze względu na zbawcze pośrednictwo Kościoła?

Już na początku zostało wspomniane, że podejście teologiczne w kwestii dialogu międzyreligijnego będzie oparte na teologii Raimundo Panikkara. Odchodząc od spekulacji na treściach czysto doktrynalnych i przechodząc do żywego dialogu pomiędzy osobami i pewnym transcendentnym przedmiotem sacrum (wymykającemu się całkowitemu poznaniu, będącym w niejakim horyzoncie), spróbuję ukazać wnioski z owej pracy.

Podobieństwo pomiędzy wiarą maryjną a czcią Guanyin jest potwierdzone nie tyle przez analizę poszczególnych wierzeń, co konkretne przykłady wzięte z sytuacji poszczególnych osób i wspólnot religijnych (chrześcijańskich, buddyjskich, synkretycznych). Postaci Maryi i Guanyin wydają się odpowiadać pewnym powszechnym i ogólnoludzkim potrzebom religijnym (kobiecemu sposobowi przejawiania się sacrum). Zapoznając się z treściami religijnymi związanymi z Guanyin, jej sposo-

${ }^{84}$ Palmer za zmianą płci Guanyin na żeńską wymienia przesłanki psychologiczne, archeologiczne i filozoficzne. Por. The Kuan-Yin Chronichles, s. 8. 
bem przejawiania się wiernym i symbolizacji, chrześcijanie mogą odkryć nowe treści w ich własnej tradycji religijnej. Doświadczenie wiary bliźniego, tj. wiara osoby zakorzenionej $\mathrm{w}$ innej tradycji religijnej wychodząca z podobnej (być może tej samej) potrzeby ukazuje nam inny sposób (przez analogię) relacji z sacrum - w tym przypadku $\mathrm{z}$ jej kobiecym obrazem, który - jak zostało ukazane - może być w procesie eksterioryzacji w przestrzeni kulturowej utożsamiany tak z Guanyin, jak i Maryją (co w przypadku kakure kirishitan występuje pod obiema postaciami na raz). Owe wierzenia, które powstają i ulegają modyfikacji na skutek ciągłego procesu, jakim jest dialog pomiędzy wierzącym a sacrum, stanowią zewnętrzny obraz owej relacji do prawdy obiektywnej ${ }^{85}$. Nie chcę jednak tutaj wchodzić na niebezpieczny grunt teologii religii proponowanej przez Hicka, twierdząc, że za manifestacjami Maryi i Guanyin/Kannon stoi jedna, święta Rzeczywistość. Chcę wskazać jedynie na pewną korelację, być może w jakimś stopniu znajdującą swe uzasadnienie w motywacjach psychologicznych (nie wykluczając archetypicznych), a przede wszystkim symbolicznych (kulturowych). Dialog pomiędzy wierzącymi ma polegać na pogłębieniu zrozumienia relacji pomiędzy naszym obrazem (przedstawieniem symbolicznym) a sacrum, jak i przez to na wzbogaceniu własnej wiary. Rozważania Panikkara odbywają się jednak zazwyczaj na poziomie czysto chrystologicznym. Ja chciałbym poddać refleksji to, czy owa relacja, która ma charakter zbawczy poprzez samą wiarę (co Panikkar sam wielokrotnie podkreśla), musi być skierowana bezpośrednio na boski Logos będący Chrystusem, czy może być zapośredniczona poprzez współodkupieńczy (niepotwierdzony dogmatycznie) charakter Maryi. Liczę na to, że wprowadzenie tych elementów, mikroopowieści, tylko przyczyni się do pogłębionej debaty na temat roli Maryi w dialogu międzyreligijnym oraz do refleksji nad postulatami mariologii. Kończąc ów tekst, chciałbym poddać pod debatę, nawiązując do dzieła Pannikara Christophany, czy możliwe są mariofanie poza obszarem Kościoła, oraz na ile gynomorficzne manifestacje sacrum $\mathrm{w}$ innych religiach mogą posiadać elementy prawdy (okruchy Logosu)? A jeśli tak, to czy wynikałoby to jedynie z naturalnych

${ }^{85}$ Ze względu na objęcie stanowiska teologicznego, stwierdzenie, że owa re-prezentacja byłaby tylko zewnętrznym przejawem potrzeb religijnych i archetypów Animy, jak i Matki, byłoby redukcjonizmem. 
zdolności (projekcji) ludzkiego umysłu oraz dążenia do Boga ${ }^{86}$, czy mogłoby być przejawem posiadanej łaski, mającej przybliżyć do Trójjedynego Boga, poprzez pośrednictwo Maryi?

Streszczenie. W artykule zostaje poruszony problem postaci Maryi i jej roli w dialogu międzyreligijnym w kontekście religii Dalekiego Wschodu. Odwołując się do koncepcji dialogu międzyreligijnego Raimundo Panikkara, próbuje się wskazać na to, co wspólne dla chrześcijańskiego kultu Maryi i buddyjskich kultów Guanyin oraz Kannon. Przytaczając dwie historie: chrześcijaństwa w Chinach epoki Tang oraz chrześcijaństwa w Japonii od czasów misji jezuickich, ukazano, w jaki sposób przenikały się wpływy i wierzenia religijne. Według teorii niektórych orientalistów możliwe, że na rozwój kultu Guanyin pod postacią kobiety w Chinach mógł mieć wpływ obecności „nestorianizmu” na tych terenach. Z kolei mamy wyraźne świadectwa wskazujące na to, że kult maryjny i kult Kannon w Japonii łączyły się ze sobą wśród wspólnot japońskich „ukrytych chrześcijan”. Dzięki obserwacji tych zjawisk możemy ujrzeć mariologię jako locus dialogu międzyreligijnego, gdzie przenikają się wzajemnie tradycje chrześcijaństwa, buddyzmu oraz religii ludowych. Postać Maryi oraz doświadczenie wiary w niej może stać się podstawą dla dalszego dialogu, jak i komparatystyki religijnej.

Słowa kluczowe: dialog międzyreligijny; mariologia; chrześcijaństwo w Azji.

Mariophany. The Figure of Virgin Mary in the Interreligious Dialogue. Author in the article tries to enter the interreligious dialogue using as his methodology the theology of interreligious dialogue of Raimundo Panikkar, which is significantly hermeneutical, making distinction between faith (action) and belief (the substance). The two micro narratives in this case, being the basis for the research, are historical events in Christian history: the clash of Christian tradition as well as: 1) Chinese civilization in Tang China; and 2) The Japanese civilization in 16th century Japan. By outlining and analyzing these two stories the author makes and attempt to enter the dialogue between Christianity and the Eastern thought, where the character of Virgin Mary is the key

${ }^{86}$ Być może postać Guanyin w buddyzmie pozwala lepiej w tym ludzkim wymiarze naturalnym dojść o własnych siłach do Boga człowiekowi nieposiadającemu łaski niż jest to w przypadku klasycznego buddyzmu Hinajana. Henri de Lubac pisze o Buddzie Śakjamuni: „Skuteczniej niż ktokolwiek inny zrealizował on pars pirificans, za co nawet chrześcijanie mogą mu być wdzięczni. Wyeliminował zwodnicze, ciągle nęcące ścieżki przesądu, mechaniczne ascezy, gnozy. Poprzez uśmierzenie zmysłów dojrzał konieczność ogołocenia się duchowego. Niewątpliwie chybił swojego celu. Bez «pełni» miłości nikt nie urzeczywistni nigdy "pustki» oderwania od świata [...] «To nie przez siebie wychodzi się z siebie»”. Można powiedzieć, że ten „brak”, tę czystą negację przełamuje w buddyzmie właśnie postać Guanyin - wzorowej bodhisattvy współczucia. 
figure. The problem which is discussed here is following: how the figure of Mary could influence and inspire the traditional Asian societies, and what is the role of Mary in the pedagogy of God's Revelation.

Key words: Interreligious dialogue; Mariology; Christianity in Asia.

\section{BIBLIOGRAFIA}

Andressen, C., Krótka historia Japonii. Od samurajów do Sony, Warszawa 2004.

Barrett, T. H., Buddhism, Taoism and the eighth-century Chinese term for Christianity: a response to recent work by A. Forte and others, "Bulletin of SOAS", 65 (2002) 3, s. 555-560.

Benko, S., The Virgin Goddess: Studies in the Pagan and Christian Roots of Mariology, Leiden, Brill 2003.

Berzin, A., The Situations of Buddhism and Islam, 1996, http://www.berzinarchives.com/ web/en/archives/study/islam/modern_interaction/situation_buddhism_islam_china.html (dostęp 20.02.2015).

Courth, F., Teksty teologiczne. Mariologia, red. E. Adamiak, Poznań 2005.

Deeg, M., Digging out God from the Rubbish Heap. The Chinese Nestorian Documents and the Ideology of Research, http://repository.kulib.kyoto-u.ac.jp/dspace/bitstream/2433/65875/15/12Deeg.pdf (dostęp 20.02.2011)

Deeg, M., The "Brilliant Teaching". The Rise and Fall of "Nestorianism" (Jingjiao) in Tang China, "Japanese Religions", vol. 21 (2), s. 91-110.

Shusaku, E., Milczenie, tłum. I. Denysko, Warszawa 1986.

Gilhooly, R., Signs of The Cross in China, “The Japan Times online”, http://search.japantimes.co.jp/cgi-bin/fv20010724a1.html (dostęp 15.01.2011).

Goddesses Who Rule, red. E. Benard, Beverly Moon, New York 2000.

Harrington, A. M., The Kakure Kirishitan and Their Place in Japan's Religious Tradition, "Japanese Journal of Religious Studies" 7 (1980) 4, s. 31--336.

Kawai, H., The Transformation of Biblical Myths in Japan, "Diogenes”, 42/1 165 (1994) 165 , s. 49-66.

Lieu, S., Epigraphica Nestoriana Serica, w: Iranica, Band. 17, Harrassowitz Verlag 2009, s. 227-246.

Nakamura, H., Pure Land Buddhism and Western Christianity Compared: A Quest for Common Roots of their Universality, "International Journal for Philosophy of Religion" 1 (1970) 2, s. 77-96.

Netland, J. T., From Cultural Alterity to Habitations the of Grace: The Evolving Moral Topography of Endo's Mudswamp Trope, "Christianity and Literature" 59 (2009) 1, s. $27-48$. 
Nosco, P., Secrecy and the Transmission of Tradition. Issues on the Study of "Underground" Christians, "Japanese Journal of Religious Studies" 20 (1993) 1, s. 3-29.

Panikkar, R., Religie świata w dialogu, tłum. J. Marzęcki, Warszawa 1986.

The Beginning of Heaven and Earth. The Sacred Book of Japan Hidden Christians, tłum. Ch. Whelan, University of Hawaii 1996.

The Kuan-Yin Chronichles. The Myths and Prophecies of the Chinese Goddess of Compassion, M. Palmer, J. Ramsey, Man-Ho Kwok, Charlottesville 2009.

The Lost Sutras of Jesus. Unlocking the Ancient Wisdom of Xian Monks, red. R. Riegert, Thomas Moore, Souvenir Press 2003.

Deeg, M., Towards a New Translation of the Nestorian Documents from the Tang Dynasty, w: Jingjiao. The Church of the East China and Central Asia, red. R. Malek in connection with P. Hofrichter, Institut Monumenta Serica 2006, s. 115-131.

Turnbull, S., Mass or Matsuri?: The Oyashiki-Sama Ceremony on Ikitsuki, "Monumenta Nipponica" 50 (1995) 2, s. 171-188.

Turnbull, S., The Kakure Kirishitan of Japan, A study of their development, beliefs and rituals to the present day, Richmond 1998.

Whelan, Ch., Religion Concealed. The Kakure Kirishitan on Narushima, "Monumenta Nipponica" 47 (1992) 3, s. 368-387.

Widengren, G., Fenomenologia religii, tłum. J. Białek, Kraków 2008.

Williams, P., Buddyzm Mahajana, tłum. H. Smagacz, Kraków 2000.

Yü Chün-Fang, Kuan-Yin, The Chinese Transformation of Avalokitesvara, New York 2001. 